\title{
The cultural and anthropological aspects of penance for religious dissent in previous centuries
}

\author{
Margarita Novak ${ }^{1,2 *}$, Sergey Borisov ${ }^{2}$, Andrey Borisovskiy ${ }^{3}$, and Anna Doborovich ${ }^{2}$ \\ ${ }^{1}$ Belgorod State Institute of Art and Culture, 308033, Belgorod, Russia \\ ${ }^{2}$ Belgorod National Research University, 308015, Belgorod, Russia
}

\begin{abstract}
The article analyses similar and different features concerning penalizing dissent in Western (Catholic) and Russian (Orthodox) culture. The authors have identified a similarity in the attempt to hide heresy behind iron bars and a difference in European penalizing practices being more egregious.
\end{abstract}

\section{Introduction}

The practices of persecuting religious dissent have existed for ages and have been noticed in the history of various religions. It must be noted, though, that persecution must be treated as an obvious violation of natural human rights and is linked to the specific understanding of the role and place of an individual in a cultural environment. Religious doctrines can regard a human given as sinful, but also regard a human being as a divine simulacrum. That may be the reason, why the history of culture knows various types of penance for different offences, but when a person defied faith penance was severe, as it meant being out of touch with the divine and was treated as blasphemy. Our group is of the opinion that the historical and anthropological aspects of penance against renegates and dissidents in the culture of the past should be thoroughly researched, for example, how different was penance for the above-mentioned offences from mundane ones. It would be interesting to compare two Christian cultures: the Eastern (Orthodox) and the Western (Catholic).

\section{The research objective and method}

The schism of the Russian Orthodox Church in the 1650-s turned old believers into renegates, though allegiance to their faith was stoic indeed. Europe had experienced significant historical events - Renaissance, Reformation, secularism, new religious trends were developing. Therefore, irrespective of the fact whether religious faith was getting stronger or not, the number of dissidents and renegates during any historical period could have been significant. As a result, the interior policy of Europe and Russia gave rise to new principles of penance and their attitude towards heretics and cult followers.

\footnotetext{
*Corresponding author: novakmargarita@yandex.ru
} 
These processes led to a similar understanding of penance both in the West and the East, though there were some differences. It is our intention to research these similar and different aspects by using the method of comparative analysis.

\section{Case analysis}

The philosophical and anthropological aspects of penance for renegates in schools of thought are not usually at the top of the list, though they have been well researched, mostly in history and law. Contributions into researching the history of religious dissent, penance and the legal foundations of monastic prisons were made by A.S.Prugavin. M.N.Gernet. I.R.Grigulevich. E.F.Gerkulov and etc. Today, this problem is studied by O.B.Molodov. T.I.Evseyev. O.E.Finogentova. A.V.Rozhina. L.B.Smirnov. N.I.Naryshkina. I.N.Ruzhinskaya. N.Yu.Kuznetsova. N.A.Belova. A.L.Eliseyev. E.S.Matveyeva. S.O.Shalyapin and others. The history of European inquisition, medieval prisons, monastic prison graffiti and penance has been thoroughly researched since ancient times to present time by such foreign researchers as F. De Boni, M.Rastrelli, V.T.Pani, M.Gazzini, M.Ferri, C.Moine, L.Sabbionesi, T.Buracchi, I.Tozzi, G.Civale, B.Bennassar, A.Prosperi, J.A. Tedeschi, S.Pastore, A.Malena, M.Firpo, M.Valente, F.Cardini, M.Montesano and others.

In the XIV century such a phenomenon as the inquisition (Inquisitio haereticae pravitatis or Sanctum officium), the search and punishment of heretics appeared. It is thought that cases of catholic inquisition were held in Russia, though they were never proved. For instance, there had been cases of persecuting old believers during the reign of tsar Alexei Mikhailovich in Russia, but they can hardly be compared with European inquisition, for each phenomenon has its own specific features, roots and history. The history of persecuting renegates is much older than the named institutions. It would be fair to say that such kind of penance appeared along with the first laws and the first officially acknowledged religious faiths. Therefore, we shall focus only on the philosophical, anthropological and cultural aspects of renegate penance and religious dissent in the Russian and European cultural environment.

The annihilation of heresies in medieval Europe was made possible by applying various ways of persuasion. The techniques were diverse, but quite a few proved to be radical. There is evidence that medieval penance in Europe was egregious and made public. It is possible that that was the reason why the penance technique was so radical and demonstrative. In the work by G.C. Lee we can read about G.Pelisson, in 1237, bearing witness to the fact that even if the heretic had died prior to his execution, his body would still be punished, for example, by burning at the stake, and, in some cases, even the bones could be extracted from the grave (Lee, 1911, p.348). One type of punishment, the so-called sanbenito, the clothes of Saint Benedict, was to publicly expose the sinner by dressing him in yellow, the colour of Judas, or red or black, the colours of the devil. The clothes bore signs, i.e. the cross of Saint Andrew, symbolizing the misfortunes which accompanied the saint throughout his life. Wearing such clothes was obviously a disgrace not only for the offender, but for his whole family. As a rule, sanbenito could have symbolized the inferno of hell. It could have gone with a hat (coroza) with the name of the offender on it. Quite often the attire would help to identify the name of the prisoner as the crowd and relatives, watching the act of faith, would fail to recognize the convict, who would be unrecognizable after torture and lengthy imprisonment. For those sentenced to burn at the stake, the clothing was similar, which was a type of cloak called samarra or samarretta. It was black with a picture of fire (Dizionario storico dell'Inquisizione, 2010, V.3, p.1361). M. Tigano points out that the investigating and processing structures of the inquisition pursued two objectives: a confession from the accused and the ideological devaluation of his views, which was supposed to provide a victory of good over evil (Tigano,2017). The 
ostensiveness of penance in the history of European culture is not surprising, especially if we remember the works of the outstanding French medievalist M. Pasturo, who confirmed the view of the enormous influence of the symbolic and visual upon the mind of the medieval European (Pasturo, 2012). In Russia, penance for dissent was not always so egregious, like exile to a remote part of the country or imprisonment in a monastery. A.M. Panchenko, with his example of punishing the fool in Christ Abraam, describes him being burnt at the stake in a roofless hut to conceal his suffering from the onlookers. As often was the case, the execution took place in 1672 in Bolotny square (Panchenko, 1999, p. 392407). So, complete and detailed ostensiveness was not the main aspect in penance practices in Russian culture. Nevertheless, a certain degree of ostensiveness did take place, like fetters and a sackcloth worn by the ascetics, etc. The exile of convicts in Russia meant that penance was practically concealed from the public. How the exiled convicts lived was revealed by writers and thinkers in the XIXth century in their publications and books. On the other hand, egregious executions in Russia were usually held as a measure to make people turn away from the evil spirit and defy heresy. N. Kollmann states that "The sentencing of schismatics usually included rallying people, so that the sight would compel them to turn away from heresy. Though the order to execute the schismatics in public would conclude the heretic books to be burnt secretly. Some descriptions have been retained of a witch or heretic being brought to the execution in a cart, so that many people could see the condemned. It has been mentioned that executions were held in Red Square and on the bank of the Moskva river opposite the Kremlin - "on the Bog" (Kollmann,2016, p.446).

The choice between physical suffering and spiritual ambivalence placed the medieval European in a crisis-ridden situation, which demanded an extreme exertion of mental power and resources to protect the spirituality of their thoughts. Physical strength was sublimated to spiritual which helped to hold on to one's views. The ambiguity of human nature (body and spirit), even its triplicity (natural, bodily, social) and personal (faith, individuality) determined the choice of severe penance: torture, spiritual transformation, severing all contacts with the surroundings. The choice of penance often was decided in favour of various executions (or physical trials) and prison, which limited altogether human manifestation, as imprisonment was equal to being buried alive: lack of contact, food, normal daily activities (no sun light in the cells), cold, darkness.

The ideal place for penance could have been the prison (or gaol), as imprisonment allowed the inmates to socialize, but, at the same time, limit the possibility to spread various theories, and apply corporal punishment, if need be. Given that the number of suspects for heresy, as well as the number of inmates could have been significant, various places were turned into prisons (sometimes, even places of residence).

The suspects could have been detained in episcopal or public prisons. Prison was not only a place of detention, but a tool for influencing religious and public life, a place for uprooting troubles. The local branches of the Roman inquisition were gradually transformed into prisons, usually in the monasteries of certain monastic orders. The headquarters of the Holy Chancellery relied on the della Rippa, Tor di Nona, Corte Savella prisons and the Castel Sant'Angelo prior to the construction of the Congregation. Other known prisons were located in such places as Siviglia nel castello di Triana in Seville, Barcelona nel Palacio de los Condes, Cordoba nell'Alcazar, in various castles of Palermo, in the royal palace of Palazzo reale, Castel San Pietro, Castello a mare and Steri. Prisons would often be set up with profits from fines. The inquisitors, in setting up the prisons, referred to the books by Bernard Gui, XIV century, Nicolau Eymerich, XIV century, Francisco Peca, XVI century, Arnau Albert,XVI century, Luis de Peramo,XVI, Spanish experts on penance, Elisio Masini and Cesare Carena, XVII century Italian experts on penance. The accused should be fed with "bread of pain and water of grief", but if they 
repented, the inquisitor could decide on a less strenuous regime which excluded chains and detention in underground cells. So, the prison could have been a tool of repentance and reconciliation. The Spanish inquisitor T. de Torquemada wrote that prison "was terrible, because it was meant for torturing the inmates rather than detaining them" (Dizionario storico dell' Inquisizione, 2010 V.1, p. 269-270). Therefore, the psychology of the inquisitor could have been reinforced by referring to solid literary sources without worrying about the chosen type of penance and heresy prosecution.

Unlike the monastic prisons, which appeared in Russia, the inquisition and medieval prisons were divided into several types; notably, different researchers classified them in different ways. Thus, it can be argued that in Russia there was an attempt to simplify the system of renegate division, though penance could have varied with regard to how serious the offence was. N. Kollmann points out that the sectarians" who wished to make the sign of the cross were subjected to corporal punishment and handed over to the local hierarchs for schooling. Those, who under torture rejected their old faith three times and denied to repent or their repentance was found to be fake, were burnt at the stake. Milder penance was inflicted upon those who could have been misled by heretic teachings. They were to be punished in accordance with their guilt and released on bail. The law prescribed corporal punishment to those who concealed schismatics: severe to those who were aware of their apostacy and milder to those who were unaware." (Kollmann, 2016, p.441442) etc. From the accounts of eyewitnesses, not only old believers and heretics were sent to monastic prisons in Russia, but mentally ill people, as well. It could have meant that those practices were undertaken by the government in order to alienate itself from anything it considered to be irrational and was not in line with the cultural and religious policy of the country and also later, during the period of an intensive cultural and historical development, when signs of the Age of Enlightenment started to appear. The expansion of monastic prisons, church reforms and the advent of old believers, the policy of tsar Alexey Mikhailovich, aimed at, among other things, the consolidation of the Church along with relations with the West - all fell into one historical timeline. Therefore, the growing influence of the Church, the intensification of heresy persecution (during that period of time everything demonic was exorcized, even roaming artists and sorcerers as bearers of the remnants of a pagan culture), as strange as it may seem, were heralds of the coming Enlightenment. Prior to the intensive development of science and education, religious texts and practices were viewed as the forerunners of a rational mindset. Unlike Europe, which came to Enlightenment through secularization and Renaissance, in Russia secularization was practically non-existent. The church schism first surfaced not among the people, but the elite, followed by a new wave of dissent. Prisons partially were the result of the fight between the rational and irrational (whereas both parties, the reformers and upholders of the Old Belief alike, tried to get hold of one or the other position in an attempt to define its world outlook in its own way.

\section{Conclusion}

Summing up what has been described, two controversial tendencies in the penance practices of religious dissent have been noticed: attempts to punish heresy in a maximum egregious way (in Western culture) against the attempts to hide the heretics in order to prevent "irrationality" and dissent from spreading (in Western and Russian culture). The choice of penance in favour of imprisonment was probably defined by the possibility to "hide the dissident" and defeat his heresy, as well.

\section{References}


1. Dizionario storico dell'Inquisizione diretto da A.Prosperi. Pisa: Edizioni Della Normale. (Scuola Normale Superiore Pisa), 3, (2010) (In Italian)

2. Dizionario storico dell'Inquisizione diretto da A.Prosperi. Pisa: Edizioni Della Normale. (Scuola Normale Superiore Pisa), 3, (2010) (In Italian)

3. M. Tigano (2017) «La giustizia ecclesiastica nel cinquecento (Ecclesiastical justice in the sixteenth century)»Vergentis. Revista de investigación de la cátedra internacional conjunta inocencio III (julio-diciembre2017). 1(5). Information on http://vergentis.ucam.edu/index.php/vergentis/article/view/61 (In Italian)

4. N.Sh. Kollmann, Prestupleniye $i$ nakazaniye $v$ Rossii rannego Novogo vremeni. (Novoye literaturnoye obozreniye, Moskva,2016) (In Russian)

5. G.Ch. Li, Istoriya inkvizitsii v Sredniye veka. T.1. (Izd.Brokgauz-Efron, SanktPeterburg, 1911). (In Russian)

6. A. M. Panchenko, Russkaya istoriya i kultura: Raboty raznykh let (Yuna, SanktPeterburg, 1999) (In Russian)

7. M. Pasturo, Simvolicheskaya istoriya evropeyskogo Srednevekovia, (Aleksandriya, Sankt-Peterburg, 2012) (In Russian) 